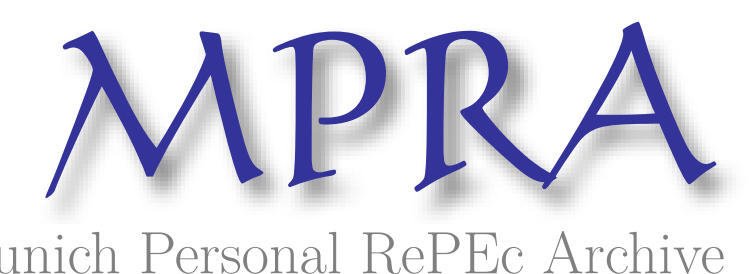

Munich Personal RePEc Archive

\title{
Capable companies or changing markets? Explaining the export performance of firms in the defence industry
}

Castellacci, Fulvio and Fevolden, Arne

January 2012

Online at https://mpra.ub.uni-muenchen.de/36026/

MPRA Paper No. 36026, posted 18 Jan 2012 16:51 UTC 


\title{
Capable Companies or Changing Markets? Explaining the Export Performance of Firms in the Defence Industry
}

\author{
Fulvio Castellacci* and Arne Fevolden ${ }^{\dagger}$ \\ * Norwegian Institute of International Affairs (NUPI), Oslo, Norway. E-mail: fc@ nupi.no \\ ${ }^{\dagger}$ NIFU, Oslo, Norway. E-mail: Arne.Fevolden@ nifu.no
}

This version: 18 January 2012

\begin{abstract}
The paper carries out an empirical analysis of the factors explaining the export performance of firms in the defence sector. We focus on the case of Norway, and make use of two complementary methodologies: the first is based on quantitative firm-level data analysis for the whole population of defence companies, and the second is based on qualitative case study research on the three most important defence export products (weapon stations, ammunition, electronics). Our empirical results highlight the importance of four major success factors for exporting firms: (1) the participation in offset agreements; (2) the ability to focus on their set of core competencies; (3) their R\&D activities and interactions with the public S\&T system; (4) demand opportunities and, relatedly, user-producer interactions.
\end{abstract}

Key words: Defence industry; liberalization; export; R\&D and innovation

JEL codes: F1; F5; L1; M2; O3 


\section{Introduction}

A new literature on firm heterogeneity and international trade has in the last few years started to investigate the determinants of export at the firm-level. Theoretical models have challenged the conventional wisdom and investigated the reasons why only a small number of enterprises within each industry are able to export, whereas most others are not (Melitz, 2003; Helpman et alia, 2004). Empirical works in this new strand of international economics and business research have pointed out a set of key factors explaining firm heterogeneity and export performance within each industry, among which firm size and productivity (Mayer and Ottaviano, 2007; Wagner, 2007), R\&D and innovation (Roper and Love, 2002; Aw et alia, 2007; Damijan et alia, 2010), and the ability of the firm to interact with external actors such as advanced users and the public science system (Alvarez et alia, 2009; Laursen, 2009).

Although this literature has led to a substantial leap forward in our understanding of firms' internationalization strategies, the focus of this research has predominantly been to point out the general factors that may be important to investigate firm dynamics for all industries in the economy, but it has so far neglected the study of how industry-specific characteristics and sectoral specificities may shape and affect firm-level patterns and dynamics.

While rooted in this emerging strand of research, this paper extends it by focusing on one specific sector that has so far received only limited attention in the international economics, innovation and business literature: the defence industry. The defence sector is in many respects a peculiar market that differs substantially from many other industries of the economy. First, defence firms are very heterogenous and produce in several different industry segments (Markowski et alia, 2010). Secondly, they invest heavily in R\&D and innovation, but the lag between input and output of the innovative process is often very long (Molas-Gallart, 1997; McLeish and Nightingale, 2007; Mowery, 2010). Thirdly, the industry is heavily regulated and protected, and public instruments such as R\&D procurement and offset agreements are commonly used to support national interests and domestic firms (Guay and Callum, 2002).

What are the factors explaining the export performance of firms in the defence industry, and how do they differ from the general framework that is typically described in the firm heterogeneity and international trade literature? The question motivating our paper is not only interesting from an academic point of view, but it is 
also highly relevant for policy. In fact, a recent EU Directive (The European Union's Defence and Security Procurement Directive 2009/81/EC) intends to provide a new framework for policy interventions in the European defence market by limiting the extent of national protection, extending cooperation and cross-border trade within the EU and eventually introducing a higher degree of market liberalization (Edwards, 2011). This EU Directive is starting to be implemented by national Member States in early 2012. The future scenario of openness and liberalization does certainly represent an important change for firms in the defence industry. This makes all the more relevant to study their current internationalization strategies, and investigate the major factors that may shape their competitive position in a more open European market in the future.

Based on this research and policy background, our paper intends to carry out an empirical analysis of the determinants of the export performance of firms in the defence industry in Norway. The Norwegian case is highly interesting. Norwegian defence companies have in the first decade of the new millennium seen their products become hugely popular abroad. Their export has on average quadrupled over the last ten years. Why is this the case - is this export success story explained mostly by firmlevel characteristics and capabilities, as the existing research would suggest, or rather by external market conditions that have favoured the foreign commercialization of a selected number of Norwegian defence products?

Our empirical analysis makes use of two complementary analyses. The first is based on quantitative firm-level data for the whole population of defence companies in Norway, and limited to the recent period 2006-2009. The second is based on qualitative case study research on the three most important defence export product types (weapon stations, ammunition, electronics), and how these have emerged historically and come to dominate the export markets in the last few years. The empirical results highlight the importance of four major success factors for Norwegian exporting firms: (1) the participation in offset agreements; (2) the ability to focus on their set of core competencies; (3) their R\&D activities and interactions with the public S\&T system; (4) demand opportunities and, relatedly, user-producer interactions.

On the whole, the paper contributes to existing research in four main directions. First, from a theoretical point of view, this is the first study on firm heterogeneity and international trade focusing on the defence industry. Secondly, in empirical terms, our 
work presents new and unique firm-level data and evidence on innovation and export in the defence sector (where data availability is usually very limited and firm-level information is highly protected and confidential). Thirdly, from a methodological point of view, our eclectic methodology combines insights from quantitative and qualitative research, and shows how these may complement each other in empirical analyses of innovation and enterprise performance. Finally, for policy, our empirical results provide information and indications that are useful to reflect upon how defence firms will respond to market liberalization when this will effectively be introduced in the defence market.

The paper is organized as follows. Section 2 presents the theoretical framework and hypothesis; section 3 describes the methodology and data; section 4 discusses the results of the quantitative firm-level analysis; section 5 illustrates the results of the three case studies; and section 6 summarizes the main findings and policy implications of the work.

\section{Theory and hypotheses}

The international economics and international business literatures flourished in the last decade provide a solid set of ideas to investigate the export performance of enterprises. However, most of these export theories and the related empirical evidence are rather general referring to firm-level patterns and dynamics across the whole economy, and have not so far focused on specific sectors. The defence industry is a rather peculiar branch of the economy, e.g. due to the great involvement of public authorities and their marked protection of national companies, the very high level of technological commitment and innovative investments, and the strong instability of demand and vulnerability to external shocks and changing political conditions.

Our strategy to cope with these specificities of the defence branch is that, while our theoretical framework is firmly rooted in the most recent strands of international economics and international business research, we will explicitly point out some specific factors and arguments that may be particularly important for analyzing the export performance of defence firms. 
Firm size: Recent models in the literature on firm heterogeneity and international trade (Melitz, 2003; Helpman et alia, 2004) have in the last few years analyzed the firm-level determinants of enterprises' export activities and pointed out the crucial importance of firm-specific characteristics such as size and productivity. ${ }^{1}$ Empirical tests of these models based on large firm-level datasets for selected countries have largely confirmed their main theoretical predictions (Bernard et alia, 2007; Mayer and Ottaviano, 2007; Wagner, 2007). In a nutshell, this literature points out that, within each industry, there is substantial heterogeneity, which is mostly accounted for by companies' characteristics such as size, productivity and capital intensity. Only a selected number of large firms (so-called superstar exporters) are able to overcome the sunk export costs and trade barriers that are faced to sell their products in foreign markets, whereas smaller and less productive enterprises are typically not able to become exporters. Thus, according to this literature, the following hypothesis should hold within each industry:

Hypothesis 1: Firm size is positively related to defence enterprises' export intensity.

It is interesting to empirically analyze this standard proposition within the context of the defence industry. The defence branch is in fact not properly a sector in the common meaning of a "homogenous group of firms producing a closely related type of products". Rather, it comprises firms belonging to different product and service categories, and it includes both large system integrators and scale-intensive producers (e.g. main battle tanks and fighter aircrafts) as well as smaller specialized suppliers of electronic components and software. In Norway, for instance, export activities are actively carried out both by large oligopolistic enterprises and SMEs. Hence, the defence industry is characterized by a firm size distribution that is less skewed than what is the case in most other sectors of the economy, and this may possibly imply that the above stated hypothesis does not hold within the context of the defence branch.

Technological innovation: A large number of empirical contributions rooted in the firm heterogeneity and international trade literature have in the last few years focused

\footnotetext{
${ }^{1}$ This theoretical literature is surveyed in Castellacci (2011a).
} 
on technological innovation as a possible key factor contributing to explain enterprises' export activities (Roper and Love, 2002; Barrios et alia, 2003; Lachenmaier and Wößman, 2006; Aw et alia, 2007; Castellani and Zanfei, 2007; Damian et alia, 2010; Ganotakis and Love, 2011). R\&D and innovative investments are expected to enhance firms' export performance for two main reasons. On the one hand, they may lead to the introduction and commercialization of new high quality products, thus increasing innovative firms' shares in foreign markets. On the other hand, $R \& D$ activities may also lead to the creation of new processes that may in turn determine higher efficiency in the production process, lower sales prices and hence stronger international competitiveness dynamics. According to the existing literature, it is therefore reasonable to argue that:

Hypothesis 2: Defence firms with higher $R \& D$ intensity have on average a stronger export performance.

Technological innovation is no doubt a crucial factor in the defence industry, which is characterized by both high private $R \& D$ investments and an active public innovation support through the procurement of $R \& D$ projects and the related defence material (Lichtenberg, 1995; Mowery, 2010). However, at the same time as formulating this second hypothesis, it is also important to point out two arguments that may blur this proposition and make it more difficult to analyze it in the defence industry than in other sectors of the economy (Castellacci, 2011b). First, the innovative process for defence companies is typically characterized by very large R\&D investments and a long time required for the innovative project to lead to a reliable and successful technological output. The long input-output lag may represent a problem for empirical analyses of the defence market, since availability of firm-level data for this industry is in general quite limited and certainly not satisfactory in terms of the (relatively short) time span that it is typically possible to consider. Secondly, a substantial share of military R\&D investments is funded by public authorities through procurement contracts. If this policy strategy crowds out private R\&D investments (David et alia, 2000), this public support may possibly turn out to lower the efficiency of R\&D activities and hence moderate their expected positive impacts on export performance. 
Cooperation with the public science and technology (S\&T) system: Universities and public research organizations represent an important partner for cooperation for innovative firms (Pavitt, 1984; Mowery, 2005). Basic scientific advances produced by the public S\&T system make it possible to increase the efficiency of the innovative process by narrowing down the search landscape and focusing on the most productive and technically feasible approaches (Nelson, 1982). Relatedly, by increasing the productivity and quality of new products and processes, advanced scientific knowledge made available to the firm is also likely to sustain its international competitiveness (Laursen and Salter, 2004; Castellacci, 2008).

This general argument is expected to assume an even greater relevance for companies in the defence industry, since many of these operate in science-based fields where the contribution of scientific research to technological developments is typically very important (e.g. electronics, ICTs, engineering, chemicals, material sciences). ${ }^{2}$ Further, the high public involvement and substantial funding efforts in this industry, motivated by national strategic and security reasons, is likely to make this type of public-private interactions even more relevant than it is the case in other sectors. Based on these arguments, we formulate our third hypothesis for the empirical analysis:

Hypothesis 3: The public $S \& T$ is an important cooperation partner for exporting firms in the defence market.

Advanced users in foreign markets: User-producer interactions represent another crucial factor explaining innovation dynamics and corporate performance (Pavitt, 1984). Collaborations with advanced users tend in fact to increase the pool of technical knowledge available to innovating firms, while at the same time supporting mutual trust, knowledge sharing and hence lower transaction costs. According to the original formulation of the 'home market hypothesis', it is domestic users that play a crucial role to raise the quality of the national markets, thus strengthening the competitiveness of firms in international markets (Fagerberg, 1995; Alvarez et alia, 2009). However, an important recent extension of this argument points to advanced users in foreign markets as a key cooperation partner for exporting firms. In fact,

\footnotetext{
${ }^{2}$ An accurate overview and classification of the different technological fields covered by firms in the defence industry is provided by the taxonomy developed by the European Defence Agency (EDA). Fevolden et alia (2009) describe knowledge and technological competencies in the Norwegian defence industry in the light of the EDA taxonomy.
} 
exporting firms face substantial sunk costs and trade barriers when they try to sale their products overseas, e.g. due to lack of knowledge of the foreign market, the lack of a distribution network, or knowledge of the local regulatory framework. Cooperation agreements with advanced users in foreign markets do therefore represent a crucial channel to overcome these trade barriers and achieve a competitive position in overseas markets (Castellacci, 2010; Ganotakis and Love, 2011). This general argument is all the more relevant for firms in the defence industry. Defence companies must in fact satisfy highly demanding customers, given the strong precision, reliability and technological sophistication that are required for military products. Only active interactions between domestic firms and foreign advanced users makes cross-order military supply a feasible and attractive option.

Hypothesis 4: Close cooperation with advanced users in foreign markets enhances defence enterprises' export performance.

Focus on core competencies: The core competence of an enterprise is a specific set of abilities or qualities that gives the firm a unique advantage and position vis-à-vis its market rivals (Prahalad and Hamel, 1990). It may refer to a set of technical knowledge and skills or some other capability or strategic characteristic of the company. It is core capabilities that make it possible for the enterprise to strive in highly competitive markets. Focusing on its set of core competencies, rather than spreading resources on a broader range of areas and product portfolio, does therefore represent an important factor for a firm to achieve a strong competitive position in international markets. According to this argument, then, the depth of the knowledge search process may be more relevant than its breadth (Laursen and Salter, 2004) in order to sustain the export intensity of an enterprise. In other words, large multiproduct firms characterized by a broad spectrum of competencies in several knowledge areas are likely to achieve a high level of total exports; by contrast, however, smaller producers specialized in a more narrow set of key core competencies and products may be in a better position to obtain greater export intensity. Since our empirical analysis will focus on firms in the Norwegian defence sector, this argument may be particularly important, given that the relative small size of the Norwegian market makes it necessary for defence companies to achieve a high 
degree of specialization in a restricted set of areas where they may have core competitive advantages vis-à-vis their foreign rivals.

Hypothesis 5: Defence firms that specialize on their core competencies are likely to have greater export intensity than enterprises characterized by a broader competence and product portfolio.

Offset agreements: Public authorities regulating the defence industry have for a long time made use of offset agreements as a policy strategy aiming at both, the protection of national security interests and the promotion of defence firms' competitiveness (Martin, 1996; Markowski et alia, 2010). Although there exists a wide range of practices and a complex array of different offset regulations, the main rationale of this type of public intervention can be summarized (and largely simplified) as follows. When country $\mathrm{X}$ imports a certain amount of defence material from a firm of country $\mathrm{Y}$, national authorities of country $\mathrm{X}$ may stipulate an offset agreement according to which the firm in country $\mathrm{Y}$ is required to purchase a corresponding amount of defence products (or a fraction of it) from a firm in country X. Intuitively, this policy scheme introduces an important support channel for defence firms, as their export contracts is not only stipulated on the basis of the price, quality or technological content of their products, but it also relies on this industrial policy practice. A related argument is that, once domestic firms are able to penetrate foreign market due to the existence of offset agreements, their presence overseas may also act as a channel to build up and develop their own production and distribution network abroad and overcome some of the related trade barriers in the future. Therefore, offset agreements may in principle have long-lasting and sizeable effects on firms' export performance.

Hypothesis 6: Offset agreements represent an important factor supporting defence firms' sales in foreign markets.

Demand opportunities: Demand conditions represent a fundamental factor shaping economic opportunities in international markets. While the demand for older and standardized products is closely dependent on their sales prices and the country's terms of trade, the commercialization of new varieties and technologically advanced products in international markets is instead more dependent on the existence of 
dynamic demand conditions and favourable market opportunities, at least in the early phase of overseas commercialization (Malerba, 2005; Von Tunzelmann and Acha, 2005). However, demand opportunities are quite difficult to account for and predict in advance for firms in the defence industry. This is in fact typically characterized by fluctuating demand conditions, which are often dependent on one or few big public customers, and which may be affected by political changes or external shocks (e.g. peace and conflicts; see Guay and Callum, 2002). Our seventh hypothesis points to the important and erratic role of demand opportunities in this market.

Hypothesis 7: Demand opportunities may change in the defence industry as a response to external shocks, and this is likely to have an important impact on the export performance of firms.

\section{Methods and data}

An appropriate methodology to carry out an empirical investigation of the determinants of firms' export performance in the defence industry must take into due account some of the key characteristics of the national market upon which the investigation focuses. The Norwegian defence sector is relatively small, with a population of approximately 100 firms. Many of these enterprises are SMEs, and a small number of large oligopolistic producers dominate both the domestic and the export markets. Further, as described in more details below, the export market is highly concentrated on a few key products that account for the bulk of Norwegian firms' foreign sales.

For our empirical analysis, these characteristics of the Norwegian defence industry call for an eclectic methodology combining both quantitative and qualitative methods. On the one hand, quantitative analysis and statistical evidence enable to point out the main stylized facts and regularities that hold for the whole population of defence firms in Norway. However, due to the relatively small size of this population and the strong concentration of production and export in the hand of a limited number of large oligopolistic firms, it is also important to complement quantitative evidence with qualitative case study research. The latter leads to a better understanding and more indepth insights of the determinants of export performance in this market precisely by 
focusing on the few key large companies and successful products that have recently driven the dynamics of this sector.

This is the eclectic approach that we have adopted in our empirical investigation. The empirical analysis is divided in two interrelated parts. The results of the first part (section 4) are based on quantitative firm-level data and statistical analysis (multivariate regressions) focusing on the recent period 2006-2009, while the second part (section 5) is based on qualitative case study research focusing on a few key large firms and crucial products that dominate the Norwegian export market, and how these have emerged and evolved in the last decades. This case study research is based on indepth interviews realized during the year 2010 with the most important Norwegian defence exporters.

The quantitative analysis (see next section) makes use of a new firm-level dataset that comprises rich and detailed information on the whole population of companies in the defence industry in Norway. ${ }^{3}$ This database, recently produced by the Norwegian Defence Research Establishment (FFI, see Fevolden et alia, 2009), is based on two different data sources. The first is firm-level account data, providing information on some of the main characteristics of the whole population of 100 defence firms, such as firm size, revenues, export and R\&D expenditures. This is cross-sectional data referring to the year 2009 .

The second is survey data obtained from the VIFIN Survey ("Verdiskaping i forsvarsindustrien”). This survey data collection work was carried out by FFI during the year 2008. The VIFIN questionnaire asked defence enterprises a large number of questions (more than 50 items) about their main characteristics, strategies, R\&D and innovation activities, interactions with external actors in the domestic and foreign markets, and internationalization strategies. These questions and the related indicators refer to the year 2006. The survey addressed the whole population of Norwegian defence firms, and obtained a total number of 45 respondent firms (response rate: $45 \%)$.

By matching these two data sources, we have obtained a combined firm-level dataset providing complete information on these 45 defence firms, which represents the sample we use in our statistical analysis. Although this is a relatively small number of observations for a regression analysis, it is important to emphasize that the companies

\footnotetext{
${ }^{3}$ This population is defined as all the firms belonging to the Norwegian Defence and Security Industries Association (FSi; www.fsi.no).
} 
in our sample account for more than $85 \%$ of the total export of defence material in Norway. This means that our data sample, despite its relatively small size, is highly representative of the whole population of Norwegian defence firms and their export performance.

Our statistical analysis (see next section) makes use of the following firm-level variables and indicators, whose descriptive patterns are reported in table 1.

Total export intensity: Total export divided by the total revenue of the firm (year 2009). This indicator will be used as the first dependent variable in our regression model. Table 1 shows that, on average, the total export intensity is above $31 \%$.

Defence export intensity: Export of defence material divided by the total defencerelated revenue of the firm (year 2009). Differently from the previous indicator, this only focuses on defence-related sales and excludes all other products of civilian use (thus avoiding the well know problem of dual use measurement bias). This indicator will be used as the second dependent variable in our regression model, and it will be the key variable of interest in our analysis. The defence export intensity (industrylevel average) is around $27 \%$.

The explanatory variables in our model will be measured through the following six indicators. $^{4}$

Firm size: Number of employees of the firm in the year 2006. The industry average is around 200, although there is a substantial variability in the sample that comprises both many SMEs as well as large enterprises.

R\&D intensity: Total R\&D divided by the firm's total revenues (year 2006). The figures for total R\&D include both the firm's own R\&D costs and its publicly funded R\&D activities. On average, more than $50 \%$ of the companies in the sample have R\&D activities, whereas the mean for all other industries in the Norwegian economy is around $12 \%$. This indicates that the defence industry is characterized by a much

\footnotetext{
${ }^{4}$ Our firm-level dataset does not contain any information about demand opportunities and/or demand shocks, which is the seventh explanatory factor highlighted in the model presented in the previous section (see hypothesis 7). Thus, our quantitative analysis is forced to disregard this variable, although this factor will be closely scrutinized in the qualitative analysis presented in section 5 .
} 
higher R\&D propensity than other sectors as well as a much higher amount of (private and public) resources devoted to innovative activities.

Cooperation with the public R\&D system: The VIFIN questionnaire asked Norwegian defence firms whether "public $R \& D$ organizations and institutions are important actors for cooperation for developing new products". The variable is categorical and takes four values, ranging from 4 ("very important") to 1 ("not important").

Advanced users in foreign markets: The enterprises participating in the VIFIN survey were also asked whether they regard "advanced foreign users in the export market an important cooperation partner for their production activities". The categorical variable ranges from 4 ("very important") to 1 ("not important").

Focus on core competencies: This indicator refers to the VIFIN survey question asking the enterprises whether they consider "focusing on core competencies and outsourcing other secondary activities" an important strategy to improve their performance. Similarly to the previous, the variable takes four values on a scale between 4 ("very important") and 1 ("not important").

Offset agreements: This is a dummy variable obtained from the question asking whether the firms have taken part in offset agreements. On average, $60 \%$ of the companies in the sample have previously had offset agreements regulating their sales overseas. $^{5}$

\section{< Table 1 here >}

\footnotetext{
${ }^{5}$ In addition to the six main explanatory variables noted here, we have also made use of two more indicators as instrumental variables in some of the regressions (as further explained in section 4): (1) Cooperation with foreign competitors: VIFIN survey question on whether the firms regard "foreign competitors an important cooperation partner for their production activities". (2) Internationalization strategy: VIFIN survey question on whether the firms regard "their internationalization strategy an important channel to increase their profitability and market performance". Both variables are measured on a scale between 4 ("very important") and 1 ("not important").
} 


\section{Empirical results I: Firm-level quantitative analysis}

The regression model presented in this section analyzes the determinants of Norwegian defence firms' export performance. The variable we seek to explain is the export intensity of firms. Specifically, we consider two dependent variables: the total export intensity of firms (including both the export of defence and civilian material), and the defence export intensity (which only refers to defence sales). The latter variable is the one of main interest for this study, although we consider it interesting to present the results also for the total export intensity variable. The explanatory factors are those pointed out in our theoretical model, and they are measured through the six indicators defined in the previous section.

The regression analysis makes use of five estimation methods: (1) OLS, which we use as a benchmark; (2) tobit, a censored regression model that takes into account the lower and upper limits of the export intensity variable; (3) median regression (i.e. a quantile regression centered at the $50^{\text {th }}$ percentile of the export intensity distribution), which is less dependent on the presence of outliers than the previous two methods; (4) 2SLS, where we consider the possible endogeneity of the regressor "advanced users in foreign markets" by means of instrumental variables; (5) IV tobit, which does also deal with the same endogeneity issue in a tobit framework. ${ }^{6}$

An econometric issue in this regression model is due to the possible multicollinearity of two of the explanatory variables: R\&D intensity and cooperation with the public S\&T system. Table 2 shows the correlation matrix. Among the explanatory factors, the highest correlation coefficient is in fact the one between the R\&D and the public cooperation variables $(+0,49)$. In a relatively small sample as the one under investigation here, the correlation between these two indicators is likely to result in a multicollinearity issue and hence a low precision of some of the estimated coefficients. To consider this problem, we have run separate regressions excluding the public cooperation variable, in order to see whether the results are affected by the inclusion or exclusion of this indicator.

\section{< Table 2 here >}

\footnotetext{
${ }^{6}$ We have instrumented the variable "advanced users in foreign markets" by means of two indicators (see definition and source in section 3): (1) the importance of the cooperation with foreign competitors; (2) the importance of the firm's internationalization strategy for its market performance. Both of these instrumental variables are significantly correlated with the endogenous variable in the first-stage regressions and uncorrelated with the error term.
} 
The estimation results are presented in table 3 (total export intensity) and table 4 (defence export intensity). As noted above, table 4 is the one of main interest for this study, but the comparison with the results in table 3 is interesting and informative. The first explanatory variable included in the model is firm size (number of employees). Table 3 indicates the existence of a positive correlation between firm size and total export intensity, although the magnitude of the estimated coefficient is quite low (see columns 2, 4, 6, 8 and 10). However, when we shift the focus to the defence export intensity (table 4), the expected relationship between size and export performance does not turn out to be significant (see columns 12, 14, 16, 18 and 20). ${ }^{7}$ This contrasts with the standard hypothesis formulated on the basis of the firm heterogeneity and international trade literature (see hypothesis 1, section 2). One possible reason explaining the lack of precision of this relationship is that, in our sample, the firms with the highest defence export intensity are not only the largest and most important enterprises dominating the Norwegian defence market (Kongsberg, Nammo, Thales Norway) but do also include several SMEs that have recently achieved a defence export intensity higher than $40 \%$. As further discussed in the next section, some of these small-size Norwegian defence firms have been able to develop core competencies and technological capabilities and thus act as specialized suppliers of larger domestic and international producers within, among others, segments of the ICT and electronics industries (see the case study in section 5.3).

The next variable presented in tables 3 and 4 is the R\&D intensity. In all of the regressions presented in the two tables, the $R \& D$ variable turns out to be not significant. Thus, differently from the standard hypothesis formulated according to the literature (hypothesis 2), our empirical results fail to identify a positive significant relationship between $R \& D$ and export intensity. Our data does in fact indicate that there is substantial heterogeneity in our firm-level sample, with some of the top exporters characterized by very high $R \& D$ intensity whereas some others by substantially lower innovative investments. This empirical result (or lack of such) is important and will be discussed further in the case study analysis presented in the next

\footnotetext{
${ }^{7}$ Following the suggestion of one of our discussants, we have carried out two additional exercises to analyze the statistical relationship between firm size and export intensity in our sample. First, we have included in the regressions the size variable in quadratic form, investigating the possibility of a Ushaped relationship. Secondly, in order to see whether the largest firms (system integrators) behave differently from all others SMEs in our sample, we have created a "system integrator" dummy variable and interacted it with the size indicator. Neither of these two exercises produced significant results.
} 
section. A more specific but important caveat, though, is that the regression analysis presented here refers to the relatively short time span 2006-2009. This may be too short a period to enable a proper measurement of the links between input and output of the innovative process, which in the defence industry is typically characterized by long $\mathrm{R} \& \mathrm{D}$ projects and protracted periods of market commercialization. The qualitative analysis presented in the next section will shed further light on this aspect by taking a longer term perspective on the historical developments of some of the key technologies and successful export products introduced by Norwegian firms.

The variable measuring the interactions between defence firms and the public R\&D system turns out, as expected, to be positively related to both total export intensity and export intensity of defence material (hypothesis 3). The size of the coefficient is higher (and more significant) for the latter, indicating that the public R\&D system is a particularly important cooperation actor for the development and foreign commercialization of new defence-related products.

The indicator measuring the importance of advanced users in foreign markets is also positively related to both total export intensity and export intensity of defence material (hypothesis 4). The magnitude of the coefficient is much higher for the defence export intensity, suggesting again that interacting with advanced foreign users is an important factor supporting the export of defence material, since it increases the trust and knowledge exchanges between producers and users, and it enables exporting firms to open up and strengthen their distribution network in foreign markets. It is also interesting to note that the size of this estimated coefficient is higher (and still significant) when the variable is treated as endogenous (see regressions 7 to 10 in table 3 , and 17 to 20 in table 4 ).

Next, the variable measuring the focus on core competencies does also perform in line with the theoretical discussion presented in section 2. Firms that are able to focus on their core competencies and outsource other secondary activities have on average a higher export intensity (hypothesis 5). Interestingly, the size of the estimated coefficient is substantially higher (almost double) for the defence export intensity dependent variable, indicating that the ability to focus on the firm's set of core competencies - rather than broadening up the technological and product portfolio - is a particularly relevant factor supporting the export of defence material.

The bottom part of tables 3 and 4 present the results for the offset agreements dummy variable. The dummy does not turn out to be a significant explanatory factor for the 
total export intensity (table 3), but the estimated coefficient gets the expected sign and statistical precision when we focus on the defence export intensity dependent variable in table 4. This confirms the important role of public procurement and offset agreements for the export of defence products (hypothesis 6). It would have of course been better to employ a more precise quantitative indicator of offset agreements instead of a simple dummy variable. However, more detailed data on offset contracts are confidential and typically not available at the firm level, so that the dummy variable used here does indeed provide interesting (although limited) evidence of their relevance for firms' international activities.

\section{< Tables 3 and 4 here >}

\section{Empirical results II: Product-based qualitative analysis}

While the quantitative analysis of firm-level data points out the most important factors explaining the export performance of Norwegian defence firms, the regression results are not able to shed further light on one key relevant issue. The export success recently achieved by Norwegian defence companies is to some extent the result of a spike in demand for a small group of products produced by a limited number of companies. Few places is this more clearly illustrated than in the Norwegian Ministry of Foreign Affairs's statistics on export of defence material. As shown in table 5, of the 20 items that the Ministry uses to classify the Norwegian export, three account for over $80 \%$ of the defence export in 2009 and were responsible for most of the growth in the last decade. These three items are (1) fire control, search, handling and countermeasure equipment, (2) ammunition and explosives, and (3) electronic equipment. If these items are combined with generally available information about the Norwegian defence industry, they can be further narrowed down to the following three more specific products and producers: (1) weapon stations produced by Kongsberg, (2) large and medium caliber ammunition by Nammo, and (3) electronic equipment, i.e. an assortment of sensor and communications equipment produced by Kongsberg and a group of small and medium-sized defence contractors, such as Thales Norway and Simrad Optronics. This section will focus on these three key Norwegian products. The case study research will take a long-run perspective on the historical emergence and 
later development of these products, point out some of their technological characteristics, focus on the firms that produced and commercialized them, and discuss the main reasons explaining the export success in each of these cases. This qualitative product-based analysis is expected to complement and refine the results of the quantitative data analysis.

\section{< Table 5 here >}

\subsection{Weapon stations}

Remotely-controlled weapon stations (RWS) are systems that allow an operator to control a turret-mounted weapon system from inside a vehicle or a vessel. A typical configuration of such a system is lightly armored vehicle like a Stryker with a heavy machine gun mounted on top of the roof. Although the most frequently stated purpose of employing a weapon station is to move the gunner from a vulnerable position on top of the vehicle to a protected position inside, the weapon station can also be equipped with sophisticated sensors that have the added benefit of improving the gunner's firing accuracy and enabling the crew inside to get a more detailed and comprehensive view of the outside battlefield.

The Norwegian engagement with remotely-controlled weapon stations can be traced back at least to the early 1990s (Andås, 2006). In the early 1990s, the Norwegian Defence Research Establishment (FFI), a public research organization, initiated a project to develop the first Norwegian remotely-controlled weapon station. Nevertheless, the researchers at FFI did not intend for this weapon station to provide the armed forces with offensive capabilities. Rather, they developed the weapon station to serve as an explosive ordinance disposal (EOD) system. The researchers at FFI envisioned that if the Norwegian airports were attacked, Norway would need a unit to clear the runways of unexploded bombs so that the airfields could be swiftly rebuilt, and they believed that a remotely-controlled weapon station would be ideal to set off these unexploded bombs without endangering the personnel. To aid them, FFI engaged the private defence contractor, Vinghøeg, which helped them develop and produce the first versions of this EOD system, a system that would later be adopted by the Norwegian armed forces - under the designation Advanced Multi Role Weapon Station (AMRWS) - and deployed, among others, in Kosovo and Afghanistan. 
Although the initial idea was to use the weapon station for explosive ordinance disposal, Vinghøeg soon realized that the same system could have a broader commercial potential as a more offensive system (Dagsavisen, 2011). Nevertheless, to realize this ambition, Vinghøeg needed access to both large-scale production facilities and a considerable marketing apparatus. Since Vinghøeg was a medium-sized defence contractor, it felt it had to solicit help from a larger company and chose to ask Kongsberg -the largest Norwegian defence company - to join them in an effort to industrialize this new type of weapon station. Kongsberg accepted Vinghøeg's invitation and together they had by the end of the 1990s developed a working prototype weapon station, which could be mounted on most military vehicles and control a small to medium caliber weapon. In the process, Kongsberg also bought the rights from Vinghøeg and became the prime contractor for the Norwegian weapon station that would later be marketed under the name 'Protector.'

In the same time span, there were other developments, across the Atlantic, that serve to explain why Kongsberg's weapon station become such an commercial success developments that were closely linked to ideas about military transformation and counter insurgency. After the cold war ended, the US no longer faced a threat from an opposing super power and was, as many of its allies, struggling with a military force that seemed ill equipped to tackle its new security related challenges. As part of the ensuing debate a concept of military transformation emerged. Although military transformation has, by some authors, been described as one of the more ambiguous and ill-defined concepts in military terminology, some ideas that would be important to Kongsberg's success have been proposed under this banner: the need for forces that combined a long reach and short response time with adequate protection and lethality. One of the lessons that the US drew from the conflicts it was engaged in during the 1990s was that its armed forces was either too heavy and immobile as the armored regiments sent to the Persian Gulf, which took six months to deploy, or too light and vulnerable as the infantry forces that were deployed in Mogadishu, Somalia, which suffered the loss of several soldiers' life (US General Accounting Office, 2002).

To remedy this situation, the US Army started as early as 1999 to develop what would later be called 'interim brigade combat teams,' a new type of forces that supposedly "could more rapidly deploy and effectively operate in all types of military operations". As part of the development of these "new type of forces," the Army awarded, in 2000, General Dynamics a contract for the production of an 'Interim Armored Vehicle,' 
which would later receive the name Stryker. ${ }^{8}$ The Stryker armored fighting vehicle provided an unforeseen and exceptional opportunity for Kongsberg. It consisted of a family of ten different vehicle variants, and General Dynamics decided to attach a Kongsberg made weapon station on six of them (Gourley, 2006). Why General Dynamics chose Kongsberg's weapon stations instead of one of its competitors is still debated: one part of the explanation is certainly that Kongsberg had a very capable weapon station and another part is that General Dynamics used the opportunity to fulfill some offset obligations that it had to Norway.

Another part of the story of the weapon station's success started shortly afterwards, when two aircrafts crashed into the World Trade center. In response to these terrorist attacks and as part of a changed political climate, the US chose to engage in two wars in close succession - one in Afghanistan in 2001 and another in Iraq in 2003. Although the US and its allies won the conventional part of these wars fairly swiftly, they got drawn into a prolonged and challenging nation building process afterwards, where insurgents relentlessly attacked their troops and tried to hamper their reconstruction efforts. In the ensuing counter-insurgency warfare, the US deployed its interim brigade combat teams ${ }^{9}$, and the Stryker and especially the Kongsberg weapon station proved to be well suited to these operations, providing the right type of protection and firepower to counter hit-and-run attacks in populated areas. This experience led the US armed forces not only to place orders for more Strykers with Kongsberg weapon stations, but also to award Kongsberg contracts for installing weapon station on other types of military vehicles (Gourley, 2006). The ensuing spike in demand also ensured Norway a high level of exports, as the delivery schedule demanded that all available production capacity had to be used and trade barriers, such as the 'Buy American Act,' had to be more leniently enforced. ${ }^{10}$

\footnotetext{
${ }^{8}$ More precisely, it awarded the contract to a joint venture between General Motors Defense and General Dynamics Land Systems, but General Dynamics would later acquire General Motors Defense.

${ }^{9}$ These units were at that time referred to as Stryker Brigade Combat Teams, and the first of these teams were deployed in Mosul, Iraq in 2003.

${ }^{10}$ Nevertheless, this leniency seems to have been a temporary measure, as Kongsberg and its subcontractors have been encouraged to build production facilities in the US for the production of future weapon stations.
} 


\subsection{Medium and large caliber ammunition}

Medium and large caliber ammunition is a product category which is usually described as ranging from $12.7 \mathrm{~mm}$ rounds for heavy machine guns up to $155 \mathrm{~mm}$ shells for artillery cannons. Medium and large caliber ammunition differs from its small caliber counterparts not only in size, but also in underlying technology. The increased dimensions allow for an inclusion of among others mechanical devices and energetic compounds in the projectile that provides this type of ammunition with a broader range of capabilities. And it is common to divide this type of ammunition into categories based on the compounds they carry or the effect they produce - such as armor-piercing, high explosive and incendiary ammunition. Although medium and large caliber ammunition is a broad category, the Norwegian export success stems from three fairly specialized products produced by Nammo Raufoss - $12.7 \mathrm{~mm}$ MP (multi-purpose) ammunition (for heavy machine guns and specialized sniper rifles), $30 \mathrm{~mm}$ MP ammunition (for the main cannon of armored personnel carriers) and M72 LAW (light anti-tank weapon) (which is a portable, shoulder fired, recoilless rifle ${ }^{11}$ ).

The $12.7 \mathrm{~mm}$ and $30 \mathrm{~mm}$ MP ammunition were not developed as isolated projects (Strandli, 2010). Rather they emerged from a larger multi-purpose concept that was conceived at Raufoss during the 1960s. The concept was discovered in two steps and the first was taken in the mid-1960s, when Raufoss was asked by the Norwegian armed forces to evaluate ammunition for their F-5 fighter-bomber. At that time, one of the scenarios that policy makers feared was that the Soviet Union would use Russian trawler boats, which were frequently observed outside the Norwegian cost, to disguise an invasion force. Raufoss therefore carry out tests of two proposed types of ammunition against a model of a trawler shipside - armor-piercing incendiary which they concluded would only penetrate the vessel without doing much damage and high explosive incendiary, which would explode outside the vessel and leave only a small bulge in the shipside. Nevertheless, the technicians of Raufoss also tried some practice rounds against the model, and they found that this ammunition would disintegrate as it penetrated the shipside and bring along a swarm of fragments into the vessel - a highly desirable effect. The result was that Raufoss developed a

\footnotetext{
${ }^{11}$ M72 is sometimes called a "bazooka," rocket propelled grenade or rocket launcher as the purpose and looks of the weapons are quite similar. Nevertheless, this is not completely correct, since the M72 fires a projectile and not a rocket.
} 
modified "training-ammunition" filled with incendiary charges that the air force adopted for its fighter-bombers.

The second step was taken in the late 1960s, when Raufoss was developing the same type of incendiary ammunition for use in the Army's air-defence cannons (Strandli, $2010^{12}$ ). On request from the Army, Raufoss had included a self-destruct charge in the projectiles to ensure that they did not fall down and cause damage in friendly territory. But when the technicians from Raufoss tested the new ammunition, an explosive effect appeared in the target as the incendiary compounds set off the self-destruct charge - an effect that according to conventional physics should have been impossible. ${ }^{13}$ Raufoss would later find that the explosive effect appeared because incendiary compounds caused a violent deflagration (combustion) of the self-destruct charge. Regardless, Raufoss was now in possession of a unique type of ammunition that had penetration, fragmentation, incendiary and blast effects. Since this implied that the ammunition could be used against a wide range of targets, Raufoss named the ammunition multi-purpose (MP). Raufoss would nevertheless spend most of the 1970s - in close cooperation with the Norwegian Defence Research Establishment (FFI) - to understand the mechanisms underlying the ammunition's effects and to qualify a wide range of multi-purpose ammunition - including $12.7 \mathrm{~mm}$ and $30 \mathrm{~mm}$ MP. Raufoss also made improvements to this ammunition during the following decades, but mostly minor, incremental innovations to make the MP ammunition more stable.

The M72 light antitank weapon has had an equally long, but perhaps somewhat less striking development story than the multi-purpose ammunition. The M72 was initially developed in the US by the company Norris Thermadore and came to Norway as part of a Nato coordinated program in the mid-1960s, where Raufoss was named 'prime contractor.' Raufoss kept improving the weapon further throughout the following decades, through the development of training ammunition and a series of incremental innovations to the launcher and projectile. Although, Raufoss experienced a relatively stable demand for the M72 throughout the 1970s, 80s and early 90s (Wang, 1996), the

\footnotetext{
${ }^{12}$ The most detailed and comprehensive account that the authors have found on the development of this ammunition was given in a speech held by Kåre Strandli in Ålesund, 15th of June, 2010. Strandli is considered to be the father of the multi-purpose concept and this description relies on a manuscript from this speech in its account for the development of this ammunition.

${ }^{13}$ To create an explosive effect you usually need a detonator and there was no detonator in the MP ammunition.
} 
M72 remained a "light" anti-tank weapon, and some military branches - such as the US Army which switched to the Swedish AT4 in the 1980s - considered its penetration ability and range to be insufficient to cover their needs. Some of the M72's main selling points have throughout most of its history remained light weight and low costs.

The conditions that led to an increased demand for the M72 and $12.7 \mathrm{~mm}$ and $30 \mathrm{~mm}$ MP seem to be quite similar to that of Kongsberg's weapon station. The asymmetric threats experienced in Iraq and Afghanistan led not only to new demands, but also to changes in the perception of the different trade-offs between performance parameters in the weapon systems. An illustrating example of this was that several of the branches within the American armed forces - which had previously considered the M72 "to be too light" - found that the M72 was more than adequate in Afghanistan and Iraq where few of the targets were heavily armored. In addition, they found that the M72's low weight and limited size allowed their soldiers to maneuver through Iraqi alleyways more easily, and its low back blast enabled them to fire from enclosed spaces without exposing themselves to hostile fire (Defence Industry Daily, 2005). The $12.7 \mathrm{~mm}$ MP also seemed well adapted to the urban warfare in Iraq and the mountain warfare in Afghanistan, as its penetration ability enabled soldiers to take out enemies hiding behind brick walls and its explosive and incendiary effects, to set technicals ablaze (Pick-up trucks with a mounted machine-gun). In addition the MP ammunition's explosive and incendiary effects have been reported to have had a demoralizing effect (psychological) effect. All of these reasons seem to have led to an increased demand for the M72 and $12.7 \mathrm{~mm}$ and $30 \mathrm{~mm}$ MP among several of the countries operating in Afghanistan and Iraq.

\subsection{Electronics}

Military electronics is a product category that is almost as wide-ranging as civilian electronics. It includes everything from underwater sonar to space-based satellites, from small microchips to large-scale surveillance systems. Compared to this spectrum of diverse electronics products, the Norwegian defence contractors operate within a couple of narrow niches. Nevertheless, electronics is still the segment of the Norwegian defence industry where companies produce the most varied set of military products, including a wide range of encryption solutions, tactical communications systems, night vision equipment, and electronic sensors such as radars, lasers and 
sonars. It is also the segment of the Norwegian defence industry comprised by the most varied group of companies, including one large multi-product firm, Kongsberg, and a couple of specialized, small and medium-sized companies such as Thales Norway, Simrad Optronics, Kitron and Saab technologies.

Although the statistics show (see figure 1) a steep increase in the export of defense electronics during the 2000s, the electronics companies themselves emphasized during the interviews that they had experienced a strong, but fairly stable demand during this decade. They pointed out that the spike in export at the end of this decade should be attributed to natural fluctuations in the defense markets and the methods that the Ministry of Foreign Affairs used to collect the data, rather than any significant increase in demand ${ }^{14}$. Nevertheless, the defense electronics companies were keen to point out that the 2000s had been a very financially rewarding decade, and they attributed this success to factors such as their ability to focus on core competencies, the close cooperation with the Norwegian Defence Research Esptablishment (FFI), and exploiting comparative advantages.

\section{< Figure 1 here >}

The first success factors that all of the interviewed defence electronics companies emphasized was their ability to focus on niche products and core competencies. Nevertheless, these defence electronics companies had a somewhat diverse understanding of what this focus on niche products and core competencies actually implies. Some of the firms maintained that their success abroad could in large parts be attributed to building core competencies by taking on the job as 'systems integrators' for a large and complex defense electronics system at home. One of these companies explained that the role as systems integrator provided insights that allowed them to better "spec" (specify) their product to meet the needs of foreign clients, and another company maintained that acting as systems integrator at home enabled them to "productify" the best parts of the system and sell it as components abroad. Other companies had yet another interpretation of what a focus on core competencies meant and put the emphasis on producing a small number of products and selling them to a

\footnotetext{
${ }^{14}$ The Ministry of Foreign Affairs collects data on the physical flow of goods rather than financial transactions. This implies that the companies could have received payment both in advance and later than they actually shipped the defence equipment.
} 
limited set of clients. One of these enterprises acknowledged that there was considerable civilian demand for its products, but said that it had chosen to limit its supply to the military market because it believed that catering to civilian clients might lead to a loss of focus on military requirements.

The second main success factor that the defence electronics companies emphasized was the close cooperation with the public research organization FFI (Norwegian Defence Research Establishment). Several of the defence electronics companies mentioned that they had collaborated with FFI on defence electronics projects over several decades and that the success that they experienced during the 2000s could in large parts be attributed to the technological innovations and insights that these projects had generated. The important role that FFI has played in Norwegian defence electronics has also been highlighted by historians such as Ørstavik (1994), Njølstad and Wicken (1997). These argued that FFI established itself as the leading Norwegian center for electronics research in the first decades after World War II and that it played a pivotal role in establishing a defence electronics industry in the country, by involving Norwegian companies in commercializing technologies that it had developed, such as asdisc (sonar) and wireless communications solutions. Although not all of these products became huge commercial successes, the initiatives fostered a strong and lasting relationship between FFI and several of the defence electronics firms, and it is this relationship that, according to the companies themselves, gave them a competitive edge in the 2000s.

A third success factor that emerged during the interviews was the ability to exploit comparative advantages. Several of the firms said that their success in the foreign markets in large parts was due to focusing on product niches where geography and history had provided Norwegians with a competitive edge. One of the defence electronics companies explained that building tactical communications solutions in Norway was especially challenging, since these communications systems had to function over long distances, across deep valleys and high mountains, and under rough weather conditions. These challenges had forced them to develop tactical communication solutions that could operate under extremely demanding circumstances, and that again had provided them with a competitive edge in Middle Eastern markets, where the customers needed communication systems that could operate during desert storms. In a similar way, the same company also explained that designing oil installations for operations at the bottom of the North Sea and 
developing navigations solutions for maneuvering along a treacherous shoreline, had helped them build better combat management systems for submarines and surface vessels. Lastly, one of the defence electronics companies also emphasized "cultural competencies" as another Norwegian comparative advantage. According to this argument, Norway is a small open economy that relies on extensive trade with other countries, and has therefore developed an acute awareness of other countries culture and needs. These cultural competencies had according to this company helped them gain contracts by better specifying their products to their customer's needs and giving a better impression of their company by behaving according to their clients' customs.

\section{Conclusions and policy implications}

The paper has carried out an empirical analysis of the main factors explaining the export performance of firms in the defence sector in Norway. After a presentation of our theoretical framework and hypotheses (section 2) and the data and methodology (section 3), the paper has presented the results of two complementary analyses. The first is based on quantitative firm-level data for the whole population of defence companies in Norway, and limited to the recent period 2006-2009 (section 4); the second is based on qualitative case study research on the three most important defence export product types (weapon stations, ammunition, electronics), and how these have emerged historically and come to dominate the export markets in the last few years. The key results of the paper and the main implications for policy can be summarized under the following four points.

First, public regulations and policy interventions in the defence industry are as wellknown extensive, and they do play an important role to foster the export performance of domestic firms in foreign markets. Specifically, both the quantitative firm-level analysis and the description of the three case studies indicate that offset agreements have had a clear role to overcome entry barriers and facilitate the initial penetration of Norwegian defence firms in international markets. However, as stated in the introduction of the article, the new EU Directive that is now starting to be implemented by EU members (and Norway) will gradually seek to introduce a greater degree of market liberalization and progressively limit the number and extent of offset agreements that national authorities will be allowed to stipulate (Edwards, 2011). This 
implies that, in a long time horizon, defence enterprises will have to rely less and less on this type of instruments of national protection, and progressively base their international competitiveness solely on their own capabilities, competencies and strategies.

This calls the attention to our second result. A summary description of Norwegian defence firms' competencies and strategies leads to point out two distinct market trajectories. On the one hand, only a few large oligopolistic enterprises (e.g. Kongsberg and Nammo) have been able to maintain their dominant position for a long time and eventually configure themselves as internationally competitive system integrators and global players in a number of different areas (see the description of the first and the second case studies). This type of trajectory largely resembles what the recent international economics literature identifies as superstar exporters, i.e. large firms that due to their greater size, productivity and capital intensity, are able to overcome trade barriers and export in several different foreign markets. On the other hand, however, a distinct trajectory is traced by a bunch of SMEs that, despite their relatively smaller size and more narrow competence and product portfolio, have been able to achieve a solid international position by providing specialized equipment and precision instruments to large defence manufacturers in foreign countries - as discussed in the third case focusing on the export of defence electronics (e.g. the companies Thales Norway and Simrad Optronics). This second typology closely corresponds to what Pavitt (1984) defined as specialized suppliers firms. The Norwegian export patterns suggest that these, by achieving a high degree of specialization in a narrow range of industry segments, may turn out to have an important role to foster small countries' participation in the global value chain. All in all, according to our empirical research, the key success factor that is common to both trajectories is not firm size per se but rather the set of core competencies that characterize each company. Thus, policy measures aimed at strengthening Norwegian firms' international competitiveness should not only focus on the restricted core of large exporters but also introduce schemes to support further the foreign market penetration of smaller specialized suppliers.

Thirdly, in such a highly sophisticated technological environment as the defence industry, firms' core competencies are closely interwined with and strongly dependent on their technological capacity and innovative activities. Our empirical analysis has kept this aspect under close scrutiny. On the one hand, both the regression and the 
case study results have highlighted the important role of the public S\&T system as a key cooperation partner for innovative firms in the Norwegian defence sector - see in particular the key role played by the public research organization FFI for the initial development of all three products analyzed in our case studies. On the other hand, we have also focused on R\&D intensity as a possibly important factor explaining firms' export performance. Our regression results, though, fail to identify any statistically significant correlation between the two variables. The case studies did however shed further light on this result (or lack of such). In the defence industry, the lag between an $\mathrm{R} \& \mathrm{D}$ project and the phase of market (and foreign market) commercialization is typically quite long, so that it is difficult to measure this relationship within the context of a relatively short time span and dataset. The first and second of our case studies - on weapon systems and ammunition - do in fact indicate that the technologies underpinning these successful export products had in all cases been introduced several years (or even decades) before these became popular items in international defence markets. An implication for policy making here is that R\&D projects - and particularly those funded by national agents through public procurement - should to the extent possible take into due account demand opportunities in overseas markets and their possible future prospects, since the export success of any new $R \& D$ project is highly dependent on the match between the technological and product characteristics, on the one hand, and market demand opportunities, on the other.

The importance of demand opportunities and changing demand conditions leads to our fourth main conclusion. The defence market is typically characterized by fluctuating demand where one or few big, often public, customers are responsible for a large share of contracts. And since these large customers are highly dependent on political conditions and exogenous shocks, market demand is often characterized by strong uncertainty and volatility. Specifically, in the Norwegian case, an overly important factor to explain the recent export success for weapon systems and ammunition is the increased market opportunities that have been created in the last decade by international political developments and new military requirements determined by the conflicts in Afghanistan and Iraq. Although these political developments and the related changing demand conditions are to a large extent difficult to predict, an important factor that may partly alleviate this problem is userproducer interactions, which is another crucial variable highlighted in our paper. In 
fact, our results show that Norwegian defence firms regard advanced users in foreign markets as an important cooperation partner to commercialize their products overseas. To the extent that well developed and long lasting collaborations between domestic and foreign producers contribute to decrease transaction costs and lower entry barriers in international markets, international collaborative projects and joint ventures may represent an important strategy for firms to achieve a greater degree of certainty and predictability about future demand conditions and share the related risks with their international partners. This type of collaborative schemes does therefore represent a potentially relevant policy measure to foster defence firms' efficiency and international activities.

\section{Acknowledgment}

The article is produced as part of the INNDEF project. Financial support from the Norwegian Research Council (FORFI programme) is gratefully acknowledged. A previous draft of the paper was presented at the workshop on Innovation and Internationalization in the Defence Industry, Oslo, August 2011. We wish to thank all the participants, and in particular Paul Nightingale, for the very helpful comments and suggestions.

\section{References}

Alvarez, I., Marin, R. and Fonfria, A. (2009): "The role of networking in the competitiveness of firms", Technological Forecasting and Social Change, 76: 410421.

Andås, H. E. (2006): "Fjernstyrte våpenstasjoner for kjøretøy og skip teknologiinnspill til FS07”, FFI-rapport - 2006/01309.

Aw, B. Y., Roberts, M. and Winston, T. (2007): "The complementary role of exports and R\&D investments as sources of productivity growth", The World Economy, 30: 83-104.

Barrios, S., Görg, H. and Strobl, E. (2003): "Explaining firms' export behaviour: The role of R\&D and spillovers", Oxford Bulletin of Economics and Statistics, 65: 475496.

Bernard, A., Jensen, B., Redding, S. and Schott, P. (2007): "Firms in international trade", Journal of Economic Perspectives, 21 (3): 105-130. 
Castellacci, F. (2008): “Technological Paradigms, Regimes and Trajectories: Manufacturing and Service Industries in a New Taxonomy of Sectoral Patterns of Innovation”, Research Policy, 37, 978-994.

Castellacci, F. (2010): "International cooperations and export participation: Evidence from a survey of service firms in Norway", NUPI Working Paper.

Castellacci, F. (2011a): "Technology, heterogeneity and international competitiveness: Insights from the mainstream and evolutionary economics paradigms", in Jovanovic, M. (ed.), International Handbook of Economic Integration, Edward Elgar.

Castellacci, F. (2011b): "How does competition affect the relationship between innovation and productivity? Estimation of a CDM model for Norway", Economics of Innovation and New Technology, 20 (7): 637-658.

Castellani, D. and Zanfei, A. (2007): "Internationalisation, innovation and productivity: How do firms differ in Italy?", The World Economy, 30 (1): 156-176.

Dagsavisen (2011): "Utpeker våpen som Norges nye olje", Håvard Therkelsen, 28th January 2011.

Damijan, J., Kostevc, C. and Polanec, S. (2008): "From innovation to exporting or vice versa?", The World Economy, 33 (3): 374-398.

David, P., Hall, B., and Toole, A. (2000): "Is public R\&D a complement or substitute for private R\&D? A review of the econometric evidence", Research Policy, 29: 497529.

Defence Industry Daily (2005): "Marines Fought the LAW, and the LAW Won", $10^{\text {th }}$ of March 2005.

Edwards, J. (2011): "The EU Defence and Security Procurement Directive: A Step Towards Affordability?", International Security Programme Paper 2011/05, Chatham House, London.

Fagerberg, J. (1995), 'User-producer interaction, learning and comparative advantage', Cambridge Journal of Economics, 19, 243-256.

Fevolden, A., Karlsen, E. N. and Ringdal E. (2008): Virkemiddelapparatet og Forsvarsindustrien i Norge, FFI-rapport 2009/02066.

Fevolden, A., Andås, H. and Christiansen, J. H. (2009): En Kartlegging av Kunnskap og Kompetanse innen Forsvarsindustrien i Norge, FFI-rapport 2009/01068.

Ganotakis, P. and Love, J. (2011): "R\&D, product innovation, and exporting: evidence from UK new technology based firms", Oxford Economic Papers, 63 (2): 279-306. 
Gourley, S. R. (2006): "Stryker scores with US tactical vehicle force", International Defence Review.

Guay, T. and Callum, R. (2002): "The transformation and future prospects of Europe's defence industry", International Affairs, 78 (4): 757-776.

Helpman,. Melitz, M. and Yeaple, S. (2004): "Export versus FDI with heterogeneous firms", American Economic Review, 94 (1): 300-316.

Lachenmaier, S. and Wöbmann, L. (2006): "Does innovation cause exports? Evidence from exogenous innovation impulses and obstacles using German micro data", Oxford Economic Papers, 58: 317-350.

Laursen, K. (2009): "The effect of knowledge sources for export performance in manufacturing and services: Danish firm-level evidence", mimeo.

Laursen, K. and Salter, A. (2004): "Searching high and low: what types of firms use universities as a source of innovation?”, Research Policy, 33(8): 1201-1215.

Lichtenberg, F. R. (1995): "Economics of defense R\&D", in K. Hartley and T. Sandler (Eds.), Handbook of Defense Economics, Volume 1, Elseveier.

Malerba, F. (2005): "How innovation differ across sectors and industries", in J. Fagerberg, D. C. Mowery \& R. R. Nelson (Eds.), The Oxford Handbook of Innovation, Oxford University Press, Oxford.

Markowski, S., Hall, P. and Wykie, R. (2010): Defence Procurement and Industry Policy: A Small Country Perspective, Routledge, London.

Martin, S. (1996): The Economics of Offsets: Defence Procurement and Countertrade. Amsterdam: Harwood.

Mayer, T. and Ottaviano, G. (2007): "The happy few: The internationalization of European firms", Bruegel Blueprint Series, Volume III.

McLeish, C. and Nightingale, P. (2007): "Biosecurity, bioterrorism and the governance of science: The increasing convergence of science and security policy", Research Policy, 36 (2007): 1635-1654.

Melitz, M. (2003): "The impact of trade and intra-industry reallocations and aggregate industry productivity", Econometrica, 71 (6): 1695-1725.

Molas-Gallart, J. (1997): "Which way to go? Defence technology and the diversity of 'dual-use' technology transfer”, Research Policy, 26 (3): 367-385.

Mowery, D. (2010): "Military R\&D and innovation", in B. Hall and N. Rosenberg (Eds.), Handbook of the Economics of Innovation, Elsevier.

Nelson, R.R. (1982), 'The role of knowledge in R\&D efficiency', Quarterly Journal of Economics, 97, 453-470. 
Njølstad, O. and Wicken, O. (1997): Kunnskap som våpen - Forsvarets Forskningsinstitutt 1946-1975, Tano Aschehoug.

Pavitt, K. (1984), 'Sectoral patterns of technical change: towards a taxonomy and a theory', Research Policy, 13, 343-373.

Prahalad, C.K. and Hamel, G. (1990): "The core competence of the corporation", Harvard Business Review , 68 (3): 79-91.

Roper, S. and Love, J. (2002): "Innovation and export performance: Evidence from UK and German manufacturing plants", Research Policy, 31: 1087-1102.

Sogner, K. (2009): "Slow growth and revolutionary change: The Norwegian ITindustry enters the global age, 1970-2005, in Fagerberg, J., Mowery, D. and Verspagen, B. (Eds.): Innovation, Path Dependency and Policy: The Norwegian Case, Oxford University Press, Oxford.

Strandli, K. (2010): "The story behind the Multipurpose-technology", Speech held in Alesund, $15^{\text {th }}$ of June 2010 .

United States General Accounting Office (2002): "Military Transformation - Army Action Needed to Enhance Formation of Future Interim Brigade Combat Teams", Report to Congressional Committees, GOA-02-442.

Von Tunzelmann, N. and V. Acha (2005), 'Innovation in "low-tech" industries', in J. Fagerberg, D. C. Mowery and R. R. Nelson (eds.), The Oxford Handbook of Innovation, Oxford University Press: Oxford.

Wagner, J. (2007): "Exports and productivity: A survey of the evidence from firmlevel data", The World Economy, 30 (1): 60-82.

Wang, T. (1996): "RA i skuddlinja - industriutvikling og strategiske veivalg gjennom 100 år”, Raufoss.

Ørstavik, F. (1994) "Forskningsingeniørene i balandingsøkonomien - FFI som kraftsentrum", in Wicken, O. (Ed.), Elektronikk-entrepen $\phi r e n e$ - studier av norsk elektronikk-forskning og-industri etter 1945, Ad Notam Gyldendal. 
Table 1: Descriptive statistics

\begin{tabular}{|cccccc|}
\hline Variable & Obs. & Mean & Std. Dev. & Min & Max \\
Total export intensity & 34 & 0.31 & 0.33 & 0 & 1 \\
Defence export intensity & 33 & 0.27 & 0.39 & 0 & 1 \\
Firm size (number of employees) & 41 & 200.6 & 425.8 & 2 & 2009 \\
R\&D intensity & 33 & 10.05 & 15.13 & 0 & 53.97 \\
Cooperation with the public science system & 44 & 2.11 & 1.06 & 1 & 4 \\
Advanced users in foreign markets & 43 & 2.79 & 1.03 & 1 & 4 \\
Focus on core competencies & & & & & 4 \\
Offset agreements & 44 & 2.57 & 0.97 & 1 & \\
\end{tabular}


Table 2: Correlation matrix

\begin{tabular}{|c|c|c|c|c|c|c|c|c|}
\hline & $\begin{array}{l}\text { Total export } \\
\text { intensity }\end{array}$ & $\begin{array}{l}\text { Defence } \\
\text { export } \\
\text { intensity }\end{array}$ & $\begin{array}{l}\text { Firm size } \\
\text { (number of } \\
\text { employees) }\end{array}$ & $\begin{array}{l}\text { Focus on core } \\
\text { competencies }\end{array}$ & $\begin{array}{l}\text { Advanced users } \\
\text { in foreign } \\
\text { markets }\end{array}$ & $\begin{array}{l}\text { Cooperation } \\
\text { with the public } \\
\text { science system }\end{array}$ & $\begin{array}{c}\text { Offset } \\
\text { agreements }\end{array}$ & $\begin{array}{c}\text { R\&D } \\
\text { intensity }\end{array}$ \\
\hline Total export intensity & 1 & & & & & & & \\
\hline Defence export intensity & 0.73 & 1 & & & & & & \\
\hline Firm size (number of employees) & 0.44 & 0.09 & 1 & & & & & \\
\hline Focus on core competencies & 0.40 & 0.57 & 0.15 & 1 & & & & \\
\hline Advanced users in foreign markets & 0.44 & 0.52 & 0.12 & 0.08 & 1 & & & \\
\hline Cooperation with the public science system & 0.55 & 0.44 & 0.29 & 0.07 & 0.32 & 1 & & \\
\hline Offset agreements & 0.22 & 0.28 & 0.31 & 0.13 & 0.04 & 0.00 & 1 & \\
\hline
\end{tabular}


Table 3: Regression results: The determinants of total export intensity

\begin{tabular}{|c|c|c|c|c|c|c|c|c|c|c|}
\hline & \multicolumn{2}{|c|}{ OLS } & \multicolumn{2}{|c|}{ Tobit } & \multicolumn{2}{|c|}{$\begin{array}{l}\text { Median } \\
\text { regression }\end{array}$} & \multicolumn{2}{|c|}{ 2SLS } & \multicolumn{2}{|c|}{ IV Tobit } \\
\hline & (1) & (2) & (3) & (4) & (5) & (6) & (7) & (8) & (9) & (10) \\
\hline Firm size (number of employees) & $\begin{array}{l}0.0002 \\
(1.54)\end{array}$ & $\begin{array}{c}0.0002 \\
(2.18) * *\end{array}$ & $\begin{array}{l}0.0002 \\
(1.62)\end{array}$ & $\begin{array}{c}0.0002 \\
(2.38) * *\end{array}$ & $\begin{array}{l}0.0002 \\
(1.72)^{*}\end{array}$ & $\begin{array}{c}0.0002 \\
(2.82) * * *\end{array}$ & $\begin{array}{l}0.0002 \\
(1.47)\end{array}$ & $\begin{array}{l}0.0002 \\
(1.89)^{*}\end{array}$ & $\begin{array}{c}0.002 \\
(1.67)^{*}\end{array}$ & $\begin{array}{l}0.0002 \\
(1.91)^{*}\end{array}$ \\
\hline $\mathrm{R} \& \mathrm{D}$ intensity & $\begin{array}{c}-0.0026 \\
(0.49)\end{array}$ & $\begin{array}{l}0.0025 \\
(0.51)\end{array}$ & $\begin{array}{c}-0.0033 \\
(0.74)\end{array}$ & $\begin{array}{l}0.0024 \\
(0.52)\end{array}$ & $\begin{array}{c}-0.0009 \\
(0.20)\end{array}$ & $\begin{array}{l}0.0002 \\
(0.07)\end{array}$ & $\begin{array}{l}-0.003 \\
(0.52)\end{array}$ & $\begin{array}{l}0.0007 \\
(0.14)\end{array}$ & $\begin{array}{l}0.0005 \\
(0.07)\end{array}$ & $\begin{array}{l}0.0016 \\
(0.28)\end{array}$ \\
\hline Cooperation with the public science system & $\begin{array}{c}0.132 \\
(2.02)^{* *}\end{array}$ & & $\begin{array}{c}0.149 \\
(2.50)^{* * *}\end{array}$ & & $\begin{array}{l}0.105 \\
(1.58)\end{array}$ & & $\begin{array}{l}0.108 \\
(1.49)\end{array}$ & & $\begin{array}{l}0.033 \\
(0.37)\end{array}$ & \\
\hline Advanced users in foreign markets & $\begin{array}{l}0.078 \\
(1.30)\end{array}$ & $\begin{array}{c}0.112 \\
(1.81)^{*}\end{array}$ & $\begin{array}{l}0.076 \\
(1.42)\end{array}$ & $\begin{array}{l}0.113 \\
(2.02)^{*}\end{array}$ & $\begin{array}{l}0.069 \\
(1.26)\end{array}$ & $\begin{array}{c}0.157 \\
(2.73)^{* * *}\end{array}$ & $\begin{array}{l}0.160 \\
(1.68)^{*}\end{array}$ & $\begin{array}{c}0.220 \\
(2.25)^{* *}\end{array}$ & $\begin{array}{c}0.244 \\
(2.17)^{* *}\end{array}$ & $\begin{array}{c}0.263 \\
(2.51)^{* *}\end{array}$ \\
\hline Focus on core competencies & $\begin{array}{c}0.119 \\
(2.16)^{* *}\end{array}$ & $\begin{array}{c}0.125 \\
(2.13)^{* *}\end{array}$ & $\begin{array}{c}0.126 \\
(2.56)^{* * *}\end{array}$ & $\begin{array}{c}0.131 \\
(2.43)^{* *}\end{array}$ & $\begin{array}{c}0.105 \\
(1.96)^{*}\end{array}$ & $\begin{array}{c}0.122 \\
(2.15)^{* *}\end{array}$ & $\begin{array}{c}0.116 \\
(1.96)^{*}\end{array}$ & $\begin{array}{c}0.119 \\
(1.84)^{*}\end{array}$ & $\begin{array}{c}0.109 \\
(1.66)^{*}\end{array}$ & $\begin{array}{l}0.109 \\
(1.63)\end{array}$ \\
\hline Offset agreements & $\begin{array}{l}0.018 \\
(0.15)\end{array}$ & $\begin{array}{l}0.029 \\
(0.23)\end{array}$ & $\begin{array}{l}0.022 \\
(0.21)\end{array}$ & $\begin{array}{l}0.034 \\
(0.29)\end{array}$ & $\begin{array}{l}0.140 \\
(1.30)\end{array}$ & $\begin{array}{l}0.161 \\
(1.33)\end{array}$ & $\begin{array}{l}0.005 \\
(0.04)\end{array}$ & $\begin{array}{l}0.011 \\
(0.08)\end{array}$ & $\begin{array}{l}0.061 \\
(0.41)\end{array}$ & $\begin{array}{l}0.062 \\
(0.41)\end{array}$ \\
\hline Constant & $\begin{array}{c}-0.501 \\
(2.27)^{* *}\end{array}$ & $\begin{array}{l}-0.407 \\
(1.77)^{*}\end{array}$ & $\begin{array}{c}-0.537 \\
(2.71)^{* * *}\end{array}$ & $\begin{array}{l}-0.424 \\
(2.01)^{*}\end{array}$ & $\begin{array}{c}-0.491 \\
(2.83)^{* * *}\end{array}$ & $\begin{array}{c}-0.570 \\
(2.48)^{* *}\end{array}$ & $\begin{array}{c}-0.651 \\
(2.32)^{* *}\end{array}$ & $\begin{array}{c}-0.647 \\
(2.11)^{* *}\end{array}$ & $\begin{array}{c}-0.826 \\
(2.48)^{* *}\end{array}$ & $\begin{array}{l}-0.827 \\
(2.43)^{*}\end{array}$ \\
\hline $\mathrm{R}^{2}$ (or pseudo $\mathrm{R}^{2}$ ) & 0.525 & 0.433 & 0.887 & 0.645 & 0.418 & 0.367 & 0.466 & 0.332 & - & - \\
\hline
\end{tabular}

Significance levels: ${ }^{* * *} 1 \% ;{ }^{* *} 5 \% ;{ }^{*} 10 \%$. Regressions (7) to (10): Endogenous variable: Advanced users in foreign markets; Instrumental variables: (1) Cooperation with foreign competitors; (2) Internationalization strategy. 
Table 4: Regression results: The determinants of defence export intensity

\begin{tabular}{|c|c|c|c|c|c|c|c|c|c|c|}
\hline & \multicolumn{2}{|c|}{ OLS } & \multicolumn{2}{|c|}{ Tobit } & \multicolumn{2}{|c|}{$\begin{array}{c}\text { Median } \\
\text { regression }\end{array}$} & \multicolumn{2}{|c|}{ 2SLS } & \multicolumn{2}{|c|}{ IV Tobit } \\
\hline & (11) & (12) & (13) & (14) & (15) & (16) & (17) & (18) & (19) & (20) \\
\hline Firm size (number of employees) & $\begin{array}{l}-0.0002 \\
(1.95)^{*}\end{array}$ & $\begin{array}{c}-0.0001 \\
(0.75)\end{array}$ & $\begin{array}{l}-0.0002 \\
(2.44)^{* *}\end{array}$ & $\begin{array}{c}-0.0001 \\
(0.99)\end{array}$ & $\begin{array}{l}-0.0002 \\
(2.31)^{* *}\end{array}$ & $\begin{array}{c}-0.0001 \\
(0.54)\end{array}$ & $\begin{array}{l}-0.0002 \\
(1.91)^{*}\end{array}$ & $\begin{array}{c}-0.0001 \\
(0.81)\end{array}$ & $\begin{array}{c}-0.0002 \\
(1.63)\end{array}$ & $\begin{array}{c}-0.0001 \\
(0.70)\end{array}$ \\
\hline R\&D intensity & $\begin{array}{c}-0.0063 \\
(1.33)\end{array}$ & $\begin{array}{l}0.0011 \\
(0.24)\end{array}$ & $\begin{array}{c}-0.0073 \\
(1.65)\end{array}$ & $\begin{array}{l}0.0016 \\
(0.35)\end{array}$ & $\begin{array}{c}-0.0054 \\
(1.13)\end{array}$ & $\begin{array}{l}0.0005 \\
(0.14)\end{array}$ & $\begin{array}{c}-0.0062 \\
(1.27)\end{array}$ & $\begin{array}{l}0.0002 \\
(0.04)\end{array}$ & $\begin{array}{c}-0.0089 \\
(1.09)\end{array}$ & $\begin{array}{c}-0.0000 \\
(0.00)\end{array}$ \\
\hline Cooperation with the public science system & $\begin{array}{c}0.174 \\
(3.00)^{* * *}\end{array}$ & & $\begin{array}{c}0.197 \\
(3.51)^{* * *}\end{array}$ & & $\begin{array}{c}0.106 \\
(1.89)^{*}\end{array}$ & & $\begin{array}{c}0.175 \\
(2.92)^{* * *}\end{array}$ & & $\begin{array}{c}0.237 \\
(2.23)^{* *}\end{array}$ & \\
\hline Advanced users in foreign markets & $\begin{array}{c}0.173 \\
(3.27)^{* * * *}\end{array}$ & $\begin{array}{c}0.202 \\
(3.31)^{* * * *}\end{array}$ & $\begin{array}{c}0.181 \\
(3.79)^{* * * *}\end{array}$ & $\begin{array}{c}0.217 \\
(3.76)^{* * *}\end{array}$ & $\begin{array}{c}0.198 \\
(3.83)^{* * * *}\end{array}$ & $\begin{array}{c}0.231 \\
(3.76)^{* * *}\end{array}$ & $\begin{array}{c}0.181 \\
(2.37)^{* *}\end{array}$ & $\begin{array}{c}0.269 \\
(2.92)^{* * * *}\end{array}$ & $\begin{array}{c}0.266 \\
(2.08)^{* *}\end{array}$ & $\begin{array}{c}0.441 \\
(3.03) * * *\end{array}$ \\
\hline Focus on core competencies & $\begin{array}{c}0.196 \\
(4.10)^{* * *}\end{array}$ & $\begin{array}{c}0.211 \\
(3.78)^{* * *}\end{array}$ & $\begin{array}{c}0.212 \\
(4.85)^{* * *}\end{array}$ & $\begin{array}{c}0.229 \\
(4.32)^{* * *}\end{array}$ & $\begin{array}{c}0.262 \\
(5.01)^{* * *}\end{array}$ & $\begin{array}{c}0.253 \\
(4.25)^{* * *}\end{array}$ & $\begin{array}{c}0.193 \\
(3.91)^{* * *}\end{array}$ & $\begin{array}{c}0.202 \\
(3.41)^{* * *}\end{array}$ & $\begin{array}{c}0.282 \\
(3.44)^{* * *}\end{array}$ & $\begin{array}{c}0.276 \\
(2.90)^{* * *}\end{array}$ \\
\hline Offset agreements & $\begin{array}{c}0.188 \\
(1.84)^{*}\end{array}$ & $\begin{array}{l}0.192 \\
(1.60)\end{array}$ & $\begin{array}{c}0.209 \\
(2.26)^{* * *}\end{array}$ & $\begin{array}{c}0.217 \\
(1.92)^{*}\end{array}$ & $\begin{array}{l}0.126 \\
(1.03)\end{array}$ & $\begin{array}{l}0.045 \\
(0.34)\end{array}$ & $\begin{array}{c}0.201 \\
(1.85)^{*}\end{array}$ & $\begin{array}{l}0.202 \\
(1.54)\end{array}$ & $\begin{array}{c}0.322 \\
(1.85)^{*}\end{array}$ & $\begin{array}{c}0.370 \\
(1.75)^{*}\end{array}$ \\
\hline Constant & $\begin{array}{c}-1.019 \\
(5.38)^{* * *}\end{array}$ & $\begin{array}{c}-0.883 \\
(4.09)^{* * *}\end{array}$ & $\begin{array}{c}-1.115 \\
(6.26)^{* * *}\end{array}$ & $\begin{array}{c}-0.971 \\
(4.65)^{* * *}\end{array}$ & $\begin{array}{c}-1.087 \\
(5.34)^{* * *}\end{array}$ & $\begin{array}{c}-0.990 \\
(4.31)^{* * *}\end{array}$ & $\begin{array}{c}-1.048 \\
(4.61)^{* * *}\end{array}$ & $\begin{array}{c}-1-033 \\
(3.77)^{* * *}\end{array}$ & $\begin{array}{c}-1.804 \\
(4.20)^{* * *}\end{array}$ & $\begin{array}{c}-1.953 \\
(3.73)^{* * * *}\end{array}$ \\
\hline $\mathrm{R}^{2}$ (or pseudo $\mathrm{R}^{2}$ ) & 0.731 & 0.609 & 1.130 & 0.802 & 0.524 & 0.420 & 0.727 & 0.583 & - & - \\
\hline
\end{tabular}

Significance levels: ${ }^{* * *} 1 \% ;{ }^{* *} 5 \% ;{ }^{*} 10 \%$. Regressions (17) to (20): Endogenous variable: Advanced users in foreign markets; Instrumental variables: (1) Cooperation with foreign competitors; (2) Internationalization strategy. 
Table 5: Total Norwegian export in the defence industry, 2000-2009.

\begin{tabular}{|c|c|c|c|c|c|c|c|c|c|c|c|}
\hline & & 2009 & 2008 & 2007 & 2006 & 2005 & 2004 & 2003 & 2002 & 2001 & 2000 \\
\hline \multirow[t]{20}{*}{ Item } & Description & & & & & & & & & & \\
\hline & 1 Hand weapons for military or other purposes & 184510000 & 146089400 & 60660000 & 24488000 & 25540000 & 11436000 & 13134000 & 3446000 & 526000 & 5042000 \\
\hline & 2 Artillery etc. & 20743000 & 2217000 & 10918000 & 13866000 & 23136000 & 174045000 & 436461000 & 12976000 & 8230000 & 510000 \\
\hline & 3 Missile systems bombs, rockets, torpedoes, mines : & 130254000 & 86249000 & 165334000 & 156070000 & 55779000 & 98710000 & 613356000 & 266283000 & 33382000 & 77865000 \\
\hline & 4 Fire control, search, handling and counter-measure & 1995253000 & 1859808000 & 1187150000 & 878628000 & 803017000 & 372141000 & 639090000 & 119216000 & 47569000 & 4149000 \\
\hline & 5 ABC-weapons etc & 737000 & 199000 & 1040000 & 0 & 611000 & 837000 & 663000 & 0 & 0 & 0 \\
\hline & 6 Ammunition, explosives, etc & 807014000 & 563931406 & 546534000 & 671676430 & 564642000 & 310410640 & 387152000 & 304236000 & 268669000 & 258448000 \\
\hline & 7 Electronic equipment, etc., not included in item 4 & 917359000 & 804150000 & 712513600 & 476292000 & 578678000 & 534955016 & 361518000 & 177544000 & 384295000 & 374072000 \\
\hline & 8 Vessels and under water equipment & 15679000 & 13924000 & 4466000 & 96937000 & 72685000 & 47017000 & 34371000 & 0 & 0 & 0 \\
\hline & 9 Aerial vehicles etc. & 167170000 & 76620000 & 198944000 & 207653000 & 200707000 & 271194000 & 320549000 & 0 & 0 & \\
\hline & 10 Tanks, armored personnel carriers and other vehicle & 6191000 & 87209000 & 29455000 & 83427000 & 34633000 & 90115000 & 83180000 & 40000 & 11476000 & \\
\hline & 11 Protection and rescue equipment designed for mili & 5776000 & 3234670 & 3877000 & 0 & 0 & 38000 & 0 & 0 & 0 & \\
\hline & 12 Hangars, containers and tents developed for militar & 0 & 0 & 100000 & 9252000 & 10343000 & 0 & 0 & 0 & 0 & \\
\hline & 13 Camouflage equipment & 0 & 0 & 0 & 0 & 0 & 0 & 0 & 0 & 0 & \\
\hline & 14 Photo materiel & 0 & 0 & 0 & 0 & 0 & 362000 & 0 & 0 & 0 & \\
\hline & 15 Quartermaster supplies: clothes, fuel, office equipr & 0 & 0 & 0 & 0 & 0 & 0 & 0 & 0 & 0 & 0 \\
\hline & 16 Simulators specially constructed or modified for tra & 152254000 & 203555000 & 212345000 & 43657000 & 10344000 & 3458000 & 43186000 & 820000 & 50799000 & 7920000 \\
\hline & 18 Software & 27809000 & 15429000 & 40267000 & 8520000 & 22061000 & 85600000 & 12975000 & 7452000 & 25289000 & 4400000 \\
\hline & 19 Materials, machines and tools etc. & 51436000 & 5903000 & 17710000 & 234063000 & 14520000 & 3631000 & 33023000 & 16228000 & 15994000 & 9596000 \\
\hline & 20 Technologies connected to equipment mention unc & 17152000 & 5153000 & 639000 & 5615000 & 7055000 & 1526000 & 38734000 & 0 & 3287000 & 12000 \\
\hline & 17) (Parts) & & & & & & & & 1387742000 & 753164000 & 319154000 \\
\hline Total & & 4499337000 & 3873671476 & 3191952600 & 2910144430 & 23751000 & 5475656 & 17392000 & 295983000 & 02680000 & 51168000 \\
\hline
\end{tabular}

Source: statistics from the Norwegian Ministry of Foreign Affairs.

Figure 1: Norwegian export of electronics products and equipment, 2003-2009.

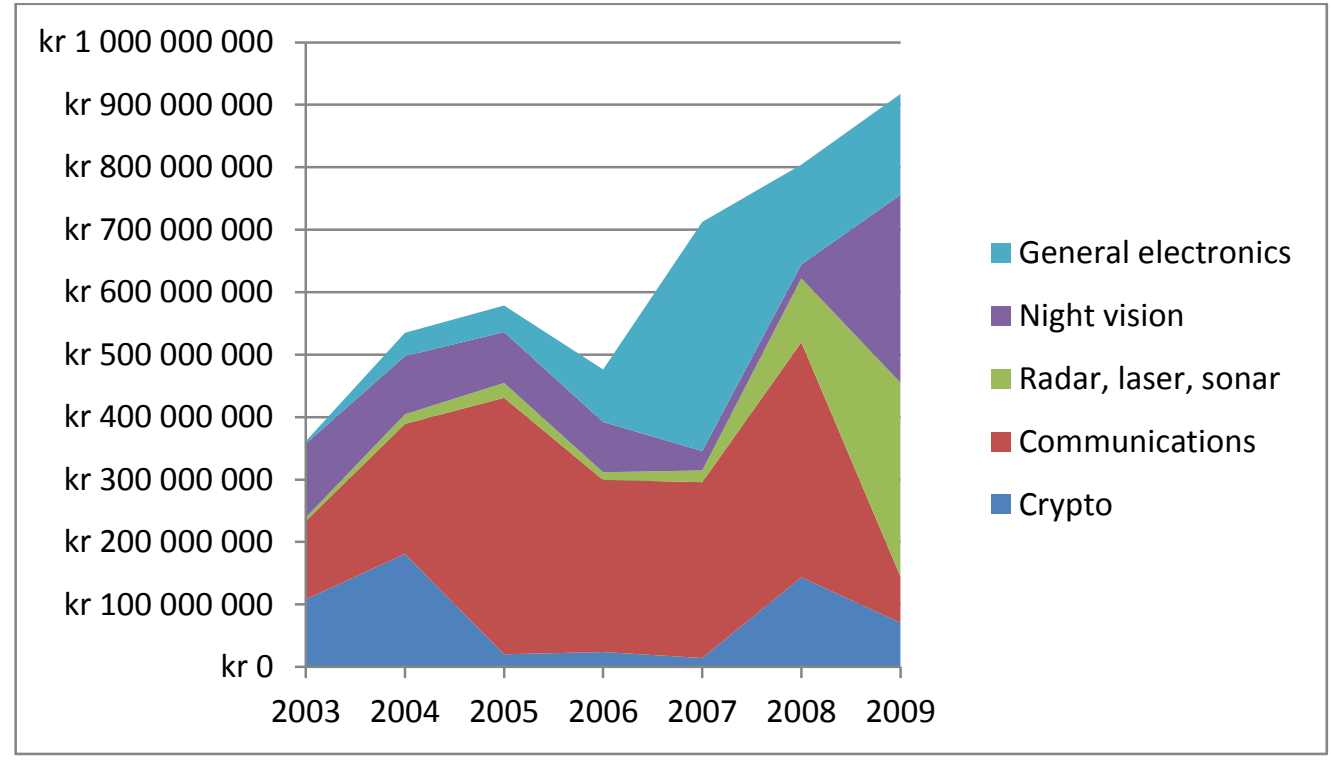

Source: statistics from the Norwegian Ministry of Foreign Affairs. 